Case Report

\title{
Bilateral Intratesticular Spermatoceles in a Critically Endangered Dama Gazelle (Nanger dama mhorr)
}

\author{
Riley E. Thompson $\mathbb{D D}^{1}$, Holly J. Haefele $\mathbb{D}^{2},^{2}$ Daniel P. O’Neil ${ }^{1}{ }^{3}$ \\ and Budhan S. Pukazhenthi $\mathbb{D D}^{1}$ \\ ${ }^{1}$ Center for Species Survival, Smithsonian Conservation Biology Institute, Front Royal, VA 22630, USA \\ ${ }^{2}$ Department of Animal Health and Research, Fossil Rim Wildlife Center, Glen Rose, TX 76043, USA \\ ${ }^{3}$ Pedernales Veterinary Center, Fredericksburg, TX 78624, USA
}

Correspondence should be addressed to Budhan S. Pukazhenthi; pukazhenthib@si.edu

Received 24 April 2020; Revised 29 June 2020; Accepted 8 July 2020; Published 17 July 2020

Academic Editor: Nektarios D. Giadinis

Copyright (c) 2020 Riley E. Thompson et al. This is an open access article distributed under the Creative Commons Attribution License, which permits unrestricted use, distribution, and reproduction in any medium, provided the original work is properly cited.

\begin{abstract}
Dama gazelles (Nanger dama mhorr) are considered critically endangered by the IUCN Red List of Threatened Species since the wild population is comprised of fewer than 200 animals. Several zoos in Europe and some private ranches in the US (Texas) maintain this species in captivity as a hedge against extinction. A routine reproductive exam on an adult male revealed bilateral cysts in the testicular parenchyma. The fluid in the cysts contained copious, moderately progressive motile spermatozoa. Following examination, the gazelle was diagnosed with bilateral intratesticular spermatoceles. Electroejaculation yielded $1.5 \mathrm{ml}$ of semen containing $387 \times 10^{6}$ total sperm with $50 \%$ motility and $45 \%$ morphologically normal sperm. The spermatoceles did not appear to cause pain or dysfunction, so no treatment was performed at this time. Since fewer than 10 animals are managed in captivity in the US, no intervention (castration/hemicastration) was considered.
\end{abstract}

\section{Introduction}

Spermatoceles and/or spermatic granulomas, a sperm-filled cystic structure similar to a spermatocele resulting in a granulomatous reaction from sperm extravasation caused by necrosis [1], have been reported in men, rams, and stallions [2-5]. Most sperm-filled cysts are localized to the caput or cauda epididymis [6]. However, spermatoceles have also been reported in the testicular parenchyma of men and rams [7]. To our knowledge, there have been no reports of spermatoceles, epididymal or intratesticular, in gazelles. This case reveals an important differential for anechoic, cystic structures seen on testicular ultrasounds of wildlife species.

\section{Case Presentation}

An adult male Dama gazelle (Nanger dama mhorr) was presented for routine reproductive examination. Animal was anesthetized (via dart; IM) using a combination of butorphanol tartrate $(0.5 \mathrm{mg} / \mathrm{kg})$, azaperone tartrate $(0.2 \mathrm{mg} / \mathrm{kg})$, and medetomidine hydrochloride $\left(0.2 \mathrm{mg} / \mathrm{kg}\right.$; $\mathrm{BAM}^{\mathrm{TM}}$, ZooPharm, Laramie, Wyoming, USA). Anesthesia was supplemented with ketamine hydrochloride $(1.0 \mathrm{mg} / \mathrm{kg} ; \mathrm{IV})$ and propofol $(0.5 \mathrm{mg} / \mathrm{kg} ; \mathrm{IV})$ to maintain an optimal anesthetic plane. Animal was subjected to a physical examination, testicular measurements, an ultrasound assessment of testes $(5 \mathrm{MHz}$ linear probe), and semen collection by electroejaculation [8]. Testicular ultrasound revealed well-demarcated, round, anechoic structures in the testicular parenchyma of both testes (Figures 1 and 2). Electroejaculation yielded $1.5 \mathrm{ml}$ semen containing $387 \times 10^{6}$ sperm with $\sim 50 \%$ total sperm motility (assessed by subjective microscopic evaluation) and $45 \%$ morphologically normal sperm (assessed using a phase contrast microscope at $1,000 \mathrm{x}$ magnification). Aspiration of the anechoic structures using a sterile hypodermic needle $(20 \mathrm{G}$; 1.5 inch) yielded a cloudy fluid with large numbers of 


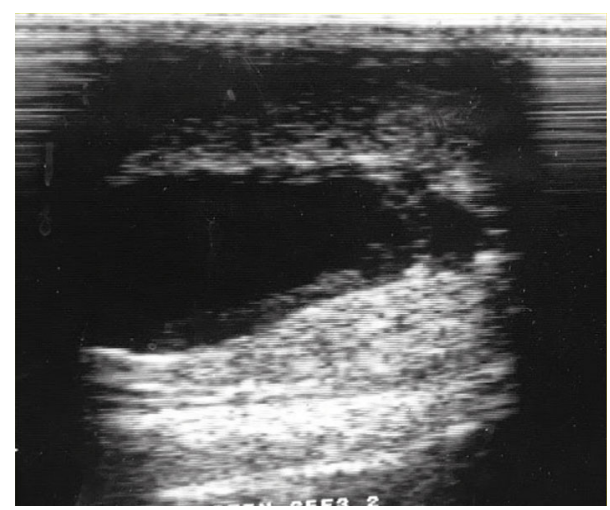

FIGURE 1: Ultrasound image of intratesticular spermatocele in a Dama gazelle.

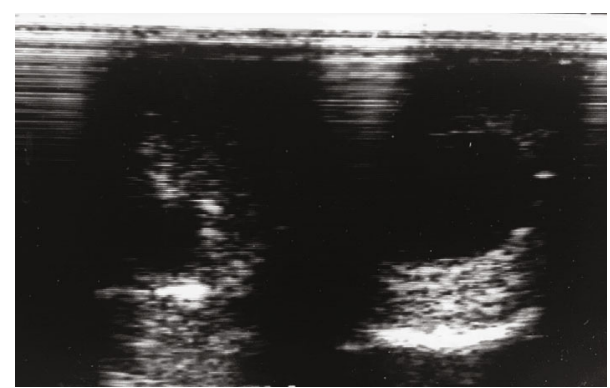

FIGURE 2: Ultrasound image of bilateral intratesticular spermatoceles in a Dama gazelle. Spermatocele appears as fluid-filled (anechoic) cystic structures.

spermatozoa with moderate progressive motility. Anesthesia was reversed using atipamezole $(1.0 \mathrm{mg} / \mathrm{kg})$ and naltrexone $(0.3 \mathrm{mg} / \mathrm{kg})$ both administered via IM injections. No treatment was performed due to lack of pain and/or testicular dysfunction. Furthermore, since Dama gazelles are critically endangered with only 10 individuals of this subspecies managed in captivity in the US, castration or hemicastration was ruled out.

\section{Discussion}

A spermatocele is a benign, sperm-filled cyst of unknown etiology [9], and a spermatic granuloma is a sperm-filled cystic structure similar to spermatoceles resulting from a granulomatous reaction due to sperm extravasation caused by necrosis [1]. The lesion in the present case was categorized as a spermatocele rather than a spermatic granuloma because the cysts were bilateral and there was no history of trauma or testicular neoplasia that could have given rise to tissue necrosis. Brucella ovis has been associated with spermatoceles and spermatic granulomas in rams [10], but there is no medical or herd history to suggest that this lesion is associated with brucellosis in this case. No information has been previously reported on the incidence of spermatoceles in Dama gazelles. Spermatoceles have been reported in rams, and most are localized to the caput or cauda region of the epididymis [6], though an intratesticular spermatocele has previously been reported in a Merino ram [7]. While most spermatoceles are small and considered incidental, if spermatoceles grow too large, they have been shown to cause pain in men [11]. In the current case, the spermatocele did not appear to cause pain or affect sperm output.

Other causes of round, anechoic structures in the testicular parenchyma include simple cysts, intratesticular abscess, and intratesticular infarction [12]. Cystic transformation of the rete testis does not typically result in a regular, round structure [12]. To distinguish between a spermatocele and other causes of round, anechoic structures in the testicular parenchyma, a needle aspirate must be performed and examined grossly and microscopically.

Three other Dama gazelles evaluated at the same time as this individual produced $1.5-4.6 \mathrm{ml}$ ejaculates containing $0.18-2.11 \times 10^{9}$ total sperm with $50-90 \%$ total sperm motility and $24-93 \%$ morphologically normal sperm. These results were comparable to the individual with the spermatoceles and to previous reports $[13,14]$. The wide variation observed in ejaculate quality among animals and the small sample size do not permit a thorough assessment of the impact of spermatocele in Dama gazelles. Hence, further studies are warranted.

\section{Conflicts of Interest}

The authors declare that there is no conflict of interest regarding the publication of this article.

\section{Acknowledgments}

Funding was provided by University of Tennessee in support of graduate assistantship to R.E.T. Additional funding was provided by the Smithsonian Institution, Mr. Mike Baudhuin, and the Phil Reed Family.

\section{References}

[1] J. E. Langer, "Ultrasound of the scrotum," Seminars in Roentgenology, vol. 28, no. 1, pp. 5-18, 1993.

[2] F. Karaca, M. Aksoy, A. Kaya, M. B. Ataman, and T. Tekeli, "Spermatic granuloma in the ram: diagnosis by ultrasonography and semen characteristics," Veterinary Radiology \& Ultrasound, vol. 40, no. 4, pp. 402-406, 1999.

[3] N. Ahmad, D. Noakes, and A. Subandrio, "B-mode real time ultrasonographic imaging of the testis and epididymis of sheep and goats," The Veterinary Record, vol. 128, no. 21, pp. 491496, 1991.

[4] J. P. Held, P. Prater, R. L. Toal, J. T. Blackford, and M. McCracken, "Sperm granuloma in a stallion," Journal of the American Veterinary Medical Association, vol. 194, no. 2, pp. 267-268, 1989.

[5] K. Ramanathan, J. Yaghoobian, and R. L. Pinck, "Sperm granuloma," Journal of Clinical Ultrasound, vol. 14, no. 2, pp. 155156, 1986.

[6] S. J. Miller and G. R. Moule, "Clinical observations on the reproductive organs of Merino rams in pastoral Queensland," Australian Veterinary Journal, vol. 30, no. 12, pp. 353-363, 1954.

[7] D. A. Watt, "Testicular abnormalities and spermatogenesis of the ovine and other species," Veterinary Bulletin, vol. 42, no. 4, pp. 181-190, 1972. 
[8] J. Wojtusik, P. Pennington, N. Songsasen, L. R. Padilla, S. B. Citino, and B. S. Pukazhenthi, "Pretreatment of Addra gazelle (Nanger dama ruficollis) spermatozoa with cholesterol-loaded cyclodextrins improves cryosurvival," Cryobiology, vol. 73, no. 3, pp. 388-395, 2016.

[9] H. H. Lee, C. J. Fong, C. T. Lai et al., "Giant spermatocele with multilocular appearance: a case report and literature review," Journal of Taiwan Urological Association, vol. 16, pp. 81-84, 2005.

[10] B. Dénes and R. Glávits, "Bacteriologically confirmed cases of ovine epididymo-orchitis caused by Brucella ovis in Sub-Carpathia," Acta Veterinaria Hungarica, vol. 42, no. 1, pp. 2533, 1994

[11] C. Huggins and W. J. Noonan, "Spermatocele, including its x-ray treatment," The Journal of Urology, vol. 39, no. 6, pp. 784-790, 1938.

[12] V. S. Dogra, R. H. Gottlieb, D. J. Rubens, and L. Liao, "Benign intratesticular cystic lesions: US features," Radiographics, vol. 21, suppl_1, pp. S273-S281, 2001.

[13] T. Abaigar, M. Cano, A. R. Pickard, and W. V. Holt, "Use of computer-assisted sperm motility assessment and multivariate pattern analysis to characterize ejaculate quality in Mohor gazelles (Gazella dama mhorr): effects of body weight, electroejaculation technique and short-term semen storage," Reproduction, vol. 122, no. 2, pp. 265-273, 2001.

[14] J. J. Garde, A. J. Soler, J. Cassinello et al., "Sperm cryopreservation in three species of endangered gazelles (Gazella cuvieri, G. dama mhorr, and G. dorcas neglecta)," Biology of Reproduction, vol. 69, no. 2, pp. 602-611, 2003. 